\title{
Original article (full paper) \\ Adaptation and validation of the Sport Multidimensional Perfectionism Scale-2 (SMPS-2) for the Brazilian sport context
}

\author{
José Roberto Andrade do Nascimento Junior \\ Universidade Estadual de Maringá, Maringá, PR, Brazil \\ João Ricardo Nickenig Vissoci \\ Faculdade Ingá, Maringá, PR, Bazil \\ David Lavallee \\ University of Stirling, Scotland, United Kingdom \\ Lenamar Fiorese Vieira \\ Universidade Estadual de Maringá, Maringá, PR, Brazil
}

\begin{abstract}
The purpose of this paper was to adapt and validate the Sport-Multidimensional Perfectionism Scale-2 (SMPS-2) for the Brazilian population using a three-step approach. For content validity, four participants translated the SMPS-2 to Portuguese and six experts adapted the content. Construct validity sample was tested with 395 athletes from a set of individual and team sports. Temporal validity was evaluated with an independent sample of 80 athletes with two data collections. Data analysis was conducted through Content Validity Coefficient (CVC), Cronbach's alpha, Composite Reliability (CR) and Exploratory (EFA) and Confirmatory (CFA) analyses. Results showed that the Portuguese version contained clear and relevant questions $(\mathrm{CVC}>.80)$ and good internal consistency $(\alpha>.70 / \mathrm{CR}>.70)$; EFA model revealed a four factor solution with 24 items as more satisfying while CFA confirmed the SMPS-2 model with 24 items was adequate. Multi-group analysis showed partial gender invariance. Temporal stability was achieved in all 24 items of the scale (ICC > .75). We concluded that the SMPS-2 is a valid measure for the assessment of perfectionism of the Brazilian sport context.
\end{abstract}

Keywords: factor analysis, psychometrics, sport psychology, measurement

Resumo - "Adaptação e validação da Escala Multidimensional de Perfeccionismo no Esporte-2 (SMPS-2) para o contexto brasileiro." O objetivo do presente trabalho foi adaptar e validar a Sport-Multidimensional Perfectionism Scale-2 (SMPA-2) para uso em população brasileira por meio de três etapas. Para a validação do conteúdo, quatro participantes traduziram a SMPS-2 para o português e seis especialistas adaptaram o conteúdo. A amostra de validação de constructo foi composta por 395 atletas de modalidades esportivas individuais e coletivas. A validade temporal foi avaliada com uma amostra independente de 80 atletas com duas coletas de dados. A análise dos dados foi realizada com o Coeficiente de Validade de Conteúdo (CVC), o alfa de Cronbach, a Confiabilidade Composta (CC) e a Análise Fatorial Exploratória (AFE) e Confirmatória (AFC). Os resultados evidenciaram que a versão em português contém questões claras e relevantes (CVC $>0,80)$; além disso, a SMPS-2 apresentou consistência interna satisfatória $(\alpha>0,70 / \mathrm{CC}>0,70)$. A AFE revelou uma solução de quatro fatores com 24 itens como mais satisfatória, enquanto a AFC confirmou que o modelo da SMPS-2 com 24 itens teve ajuste satisfatório. A análise multigrupos apontou invariância de gênero parcial. Foi obtida a estabilidade temporal da escala com 24 itens (ICC $>0,75$ ). Concluiu-se que a SMPS-2 é um instrumento válido para a avaliação do perfeccionismo no contexto esportivo brasileiro.

Palavras-chave: análise fatorial, psicometria, psicologia do esporte, medida

Resumen - “Adaptación y Validación de la Escala Multidimensional de Perfeccionismo en el Deporte-2 (SMPS-2) para el contexto brasileño." El objetivo del presente trabajo ha sido adaptar al portugués y validar la Sport-Multidimensional Perfectionism Scale-2 (SMPS-2) para uso en población brasileña a través de tres pasos. Para ello, cuatro participantes han traducido la SMPS-2 al portugués y seis especialistas han adaptado el contenido. La muestra de validación de constructo ha sido compuesta por 395 deportistas de modalidades individuales y colectivas. La validación temporal fue avaluada con una muestra independiente de 80 jugadores en dos momentos. Para el análisis de los datos, se han utilizado el Coeficiente de Validez de Contenido (CVC), el alfa de Cronbach, la Confiabilidad Compuesta (CC) y el Análisis Factorial 
Exploratorio (AFE) y Confirmatorio (AFC). De los resultados se desprende que la versión en portugués contiene preguntas claras y relevantes $(\mathrm{CVC}>0,80)$. Además la SMPS-2 ha presentado consistencia interna satisfactoria $(\alpha>0,70 / \mathrm{CR}>$ $0,70)$. El AFE reveló solución de cuatro factores con 24 artículos como más satisfactorios, ya que la AFC confirmado que el modelo de 24 SMPS-2 tenía los elementos de ajuste satisfactorios. El análisis multigrupos ha señalado que no hay varianza de género parcial. Se ha obtenido estabilidad temporal de la escala con 24 artículos (ICC $>0,75)$. Se puede concluir que la SMPS-2 es un instrumento válido para la evaluación del perfeccionismo en el contexto deportivo brasileño.

Palabras claves: análisis factorial, psicometría, psicología del deporte, medición

\section{Introduction}

Perfectionism is a personality trait that has become increasingly important within sport and exercise studies as a characteristic associated with adaptive and maladaptive outcomes (Dunn, Causgrove Dunn \& Syrotuk, 2002; Flett \& Hewitt, 2005; Gotwals, Stoeber, Dunn \& Stoll, 2012; Stoeber \& Otto, 2006). It is a multidimensional construct and defined as an individual's desire to reach a flawless performance, generally seeking high achievements standards established by oneself or his/her peers (Flett \& Hewitt, 2002). Thus, the ability to adequately evaluate perfectionism is a current need to the development of sport and sport psychology sciences in general, especially in Brazil where no such instrument has been validated for sport contexts.

Perfectionism is a domain-specific concept (Dunn, Gotwals, $\&$ Causgrove Dunn, 2005). Therefore, the way perfectionism is understood within sports context might differ from the way it is applied in other environments such as work or family. Hence, evaluating perfectionism with a sport specific instrument is determinant. However, to the extent of our literature review, no sport specific perfectionism scale has been validated to Brazilian context. Also, further research is needed to provide more evidence of internal structure validity for one of the most used perfectionism scales in sport settings (Sport Multidimensional Perfectionism Scale-2/ SMPS-2) (Gotwals, Dunn, Causgrove Dunn \& Gamache, 2010).

To this date, despite a number of studies reporting reliability indicators of perfectionism's theoretical model evaluated by SMPS-2 (Dunn, Gotwals, Causgrove Dunn \& Syrotuk, 2006; Gotwals et al., 2010; Parker \& Adkins, 1995; Soares, Gomes, Macedo, \& Azevedo, 2003), there is not a consensus in the literature about the coherence of its internal structure, provided by confirmatory measures for latent models such as confirmatory factor analysis. There is, although, evidence supporting the latent model; however these results do not imply that the 42 items scale is internally consistent (Gotwals et al., 2010). Actually, few studies have evaluated SMPS-2's validity with cross-cultural studies and with different performance level samples. Furthermore, several psychometric properties were tested and validated but internal structure has repeatedly been reported as inconsistent (Gotwals \& Dunn, 2009).

The most common measurement instruments used to investigate perfectionism include the Frost-Multidimensional Perfectionism Scale/FROST-MPS (Frost, Marten, Lahart Rosenblate, 1990) and Hewitt-Multidimensional Perfectionism Scale/ HEWITT-MPS (Hewitt \& Flett, 1991). Both instruments are oriented to evaluate two general dimensions broadly accepted in perfectionism studies, the intrapersonal (originated from the in- dividual himself) and interpersonal (originated externally) (Flet $\&$ Hewitt, 2002). However, they both differ in the way perfectionism is approached to measure both theoretical dimensions. Frost's scale evaluates six dimensions of perfectionism (personal standards, concern over mistakes, parental criticism, parental expectations, doubts in action and organization) while Hewitt's focused on three dimensions (self-oriented perfectionism, socially prescribed correlations, other-oriented perfectionism).

In sport, the majority of perfectionism studies to date have employed FROST-MPS (Dunn et al., 2002; Gotwals \& Dunn, 2009). Nevertheless, as mentioned previously, further evidence is required for domain-specific measurement instruments. In this sense, a generalist perfectionism scale might not adequately represent the construct (Gotwals et al., 2010). In order to address the context-specific needs in sport, the Sport Multidimensional Perfectionism Scale/SPORT-MPS (SMPS) (Dunn et al., 2006) was developed.

Despite SMPS's advances, inconsistencies were still observed with psychometric properties and theoretical structure. SMPS was developed based on the multidimensional perfectionism model (Frost et al., 1990), evaluating four domains (i.e., Personal Standards, Concern Over Mistakes, Perceived Parental Pressure, Perceived Coach Pressure). However, two domains (Doubts in Action and Organization) were excluded for not showing adequate psychometric indicators (Dunn et al., 2002). Subsequent research directed to the relevance of these two domains to the evaluation of interpersonal and intrapersonal dimensions of perfectionism in sport suggested that SMPS's first version might not represent perfectionism adequately, thus resulting in the development of SMPS-2 (Dunn et al., 2006; Gotwals \& Dunn, 2009).

A Sport Multidimensional Perfectionism Scale-2/SMPS-2 (Gotwals \& Dunn, 2009; Gotwals et al., 2010) was developed in order to address the deficiencies found in SMPS, including items to evaluate Doubts in Action and Organization domains, excluded in the first version. However, SMPS and SMPS-2 have demonstrated stable psychometric properties in different studies/ samples, but some inconsistencies have been repeatedly reported in relation to internal coherence. Non-adequate adjustment indexes have been found when testing perfectionism's latent model (Dunn et al., 2006; Gotwals \& Dunn, 2009; Gotwals et al., 2010). All results about internal structured have generally been based on exploratory methods and not confirmatory to actually test the measurement model.

SMPS-2 has been widely used in recent studies with athletes with different ages and characteristics (Gotwals et al., 2012). Cross-cultural adaptation to Portugal was found for SMPS's first version (Serpa, Alves, \& Barreiros, 2004), but SMPS-2 has not 
been adapted and validated to Portuguese language or Brazilian sports contexts. In Brazil, perfectionism has been evaluated with FROST-MPS and HEWITT-MPS (Soares et al., 2003) since no domain-specific instruments have been validated. Thus, our aim was to adapt and validate the Sport Multidimensional Perfectionism Scale-2 (SMPS-2) to the Brazilian context, aiming specifically to assess the content validity, construct validity (internal reliability, exploratory and confirmatory factor analysis), and temporal stability of the instrument.

\section{Method}

\section{Step one - Content validity}

\section{Participants and data collection}

A translation and cross-cultural adaptation expert group was constituted by thirteen professionals (four sworn translators and six $\mathrm{PhD}$ professors in sport psychology), who accepted freely to develop the translation, adaptation, and content validation process of the SMPS-2. After finalizing content validation a pilot study was conducted with a group of 20 athletes, who were selected by convenience and stratified by gender, aiming to assess the instrument questions about quality and coherence of language and content (Marôco, 2010). All participants provided informed consent to participate in the study.

\section{Instrument and procedures}

The Sport-Multidimensional Perfectionism Scale-2 (SMPS2) by Gotwals and Dunn (2009) was used for the adaptation and validation process. This instrument assesses perfectionist tendencies by athletes and consists of 42 items across six subscales: Personal Standards; Concern over Mistakes; Perceived
Parental Pressure; Perceived Coach Pressure; Doubts about Action; Organization (Table 1).

Answers are given on a five-point Likert type- scale $(1=$ strongly disagree to $5=$ strongly agree). Each subscale score is calculated from the average of the sum of the items answers with which it is composed. Higher values in each dimension mean greater orientation in the target domain. Both methods for obtaining results through the medium of the items as well as the interpretation of such values were proposed by the authors of the original instrument (Gotwals \& Dunn, 2009).

Approval for the study was obtained with the Ethics Committee in Human Research of the State University of Maringá (Document \# 131.681/2012). Initially, formal authorization for the translation and validation of this instrument in Brazil was requested to Professor John Dunn, author of the original instrument in Canada. Sworn translators and experts in sport psychology, psychometrics and human development were contacted to translate and evaluate the clarity and relevance of the SMPS-2 items. We contacted experts in the fields who had published papers on the topic of perfectionism in sport and non-sport settings, using the Lattes platform, which is a database of researcher's résumés in Brazil. A total of $40 \mathrm{PhD}$ researchers were contacted by email. Three responded and agreed to participate in the study. Three more $\mathrm{PhD}$ reviewers, familiar the authors of this study, were included among Psychology researchers with known expertise on psychometrics.

This experts' evaluation was initially individualized through a questionnaire and later performed together through a Delphi panel (Okoli \& Pawlowski, 2004). A five-point Likert scale was used to verify the practical relevance and language clarity of the translated instrument (content validity), answered by the evaluators judges. These scales allowed for the investigation of the consistency of the judges' opinions relating to the items of the instrument. In this scale we asked the judges to rate each translated item in terms of their clarity (easy to understand), pertinence (if they should be included in the test) and to classify which hypothesized dimension would be composed by that item.

Table 1. Dimensions of the Sport Multidimensional Perfectionism Scale-2 (SMPS-2).

\begin{tabular}{|c|c|c|}
\hline Dimensions & Items & Description \\
\hline Personal Standards (PS) & $1,8,17,21,23,33,36$ & $\begin{array}{l}\text { It includes personal expectations and excessive demands that athlete establishes for } \\
\text { in competition and as a sportsman. }\end{array}$ \\
\hline $\begin{array}{l}\text { Concern over Mistakes } \\
(\mathrm{COM})\end{array}$ & $\begin{array}{l}2,10,16,24,28,32 \\
39,42\end{array}$ & $\begin{array}{l}\text { It points out the athlete's negative feelings in relation to the possibility of failure in } \\
\text { the competition and or poor performance, as well as the belief that mistakes result } \\
\text { in a loss of respect from other athletes. }\end{array}$ \\
\hline $\begin{array}{l}\text { Perceived Parental Pressure } \\
\text { (PPP) }\end{array}$ & $\begin{array}{l}4,7,11,15,19,25,29 \\
38,40\end{array}$ & $\begin{array}{l}\text { It describes the athlete's perceptions about the high expectations of parents and } \\
\text { criticisms when athlete does not achieve high levels of performance in the competition. }\end{array}$ \\
\hline $\begin{array}{l}\text { Perceived Coach Pressure } \\
(\mathrm{PCP})\end{array}$ & $6,13,22,26,30,35$ & $\begin{array}{l}\text { It refers to the athlete's perceptions about high levels of performance established by } \\
\text { the coaches as well as negative interactions established with the coaches when the } \\
\text { athlete does not achieve high levels of performance in the competition. }\end{array}$ \\
\hline $\begin{array}{l}\text { Doubts about Action } \\
\text { (DA) }\end{array}$ & $3,12,14,20,31,37$ & Excessive tendency to doubt about own performance. \\
\hline $\begin{array}{l}\text { Organization } \\
\text { (OR) }\end{array}$ & $5,9,18,27,34,41$ & It refers to the emphasis on the importance of order and organization. \\
\hline
\end{tabular}


Regarding double translation (reverse and independent back translation), two native Portuguese language translators were initially hired independently to translate the SMPS-2 into Brazilian Portuguese language. Two other native English language translators were then hired to convert the Portuguese translated versions back to English. English translated versions were compared with the original version of the instrument. Issues with vocabulary and expressions were discussed and adjustments were addressed by the researchers and the expert group. Portuguese versions were reviewed and some corrections were conducted by the expert group in relation to technical terms and adaptation of the items to the Brazilian context (terms "padrão" was replaced by "nível" in items 4, 23 and 25 and term "praticam" was replaced for "jogam" in item 36). Portuguese versions were unified resulting in the final version of the instrument (Pasquali, 2010).

Theoretical analysis of the initial 42 items of the SMPS-2 was performed through content validity (Hernández-Nieto, 2002). This technique also checks judges' agreement regarding items classification in their dimensions. Content validity analysis considering clarity of language and practical relevance was performed by a coefficient for each item of the instrument (CCVi) and for the questionnaire as a whole (CCVt). Six judges answered a spreadsheet that included: (a) items evaluation; (b) three criteria for analysis and (c) a field for notes if judges wanted to make suggestions, add or remove any item. Criteria for analysis were clarity of language, practical relevance and theoretical dimension to which the item belongs. After the adaptation process, a pilot study was performed with the final version of the instrument in 20 male and female athletes of different sports

\section{Data analysis}

For content validity coefficient calculation, a guiding principles commonly accepted in the specialized literature (Hernandez-Nieto, 2002), with a cutoff of .80 was used. We used the Kappa coefficient $(>.75)$ to analyze the concordance index between judges for the theoretical dimensions of the items.

\section{Step two - Construct validity}

\section{Participants and data collection}

After cross-cultural adaptation and content validity, internal consistency and construct validity of the SMPS-2 were tested. The sample was initially 428 male and female adult athletes; however 33 participants did not answer one or more items of the instrument. Thus, these subjects were excluded from the study, since missing values might influence the model fit. Therefore, our final construct validation sample was composed by 395 adult athletes from team and individual sports (186 female and 209 male) participating in the final phase of the Paraná State Open Games (JAPS)-2012. Athletes were from different regions of Brazil with an average age of $22.53 \pm 5.92$ years.
The sample size for EFA and CFA was determined based on the recommendations of at least 10 subjects per item of the instrument (Hair et al., 2005). Although, due to sample loss mainly because of answering errors, our final sample had not achieved the average of 10 subjects per item; the average in this study was 9 subjects per item. To ensure sample adequacy we applied a Monte Carlo Bootstrapping technique and calculated the power for the analysis (MacCallum, Browne, \& Sugawara, 1996). Participants were devoted to the following modalities: athletics (33); basketball (23); beach volleyball (38); cycling (12); handball (75); indoor football (24); judo (38); rhythmic gymnastics (10); rugby (15); swimming (43); taekwondo (42); tennis (10) and volleyball (32).

Study inclusion criteria were to: 1) have participated in national competitions during the 2012 season; 2) have participated in the modality's State Championship during the 2011/2012 season; 3) be qualified for the finals of the JAPS 2012, thus, representing the best athletes and high performance teams; and 4) provide (signed) informed consent to participate in the study.

\section{Instrument and procedures}

The instrument used was the Sport-Multidimensional Perfectionism Scale-2 (SMPS-2), which was translated and adapted to Brazilian context in Step 1. Regarding data collection, we contacted Paraná State Department of Sports (JAPS organizer commission) in order to obtain approval for the research with athletes and teams participating in the competition. We then sent the informed consents to the players who agreed to participate in the research. SMPS-2 application was conducted in the athletes' accommodations in the city where the competition took place in the second half of 2012.

\section{Data analysis}

Data was analyzed using SPSS version 19.0 and Amos version 17.0. Sample characteristics data were analyzed descriptively (mean and standard deviation) for continuous data and frequency (percentage) for categorical data. With the Portuguese adapted version of SMPS-2 we calculated Cronbach's alpha and composite reliability (internal consistency), exploratory (EFA) and confirmatory factor analysis (CFA) (factorial validity) to verify construct validity of the instrument through: a) items individual reliability; b) absolute, incremental and parsimonious fit indexes; and c) average variance extracted to examine the convergent validity (Devellis, 2003; Kline, 2012).

Since the SMPS-2 has been repeatedly reported with inconsistencies in its latent structure (Gotwals \& Dunn, 2010), we opted to approach construct validity initially with an exploratory methodology to check the theoretical dimensionality in its Portuguese translated version. Matrix correlations were calculated to evaluate the association between items in their hypothesized dimensionality clustering. EFA was conducted through Unweighted Least Square with a Direct Oblique Rotation (Oblimin). 
Initially, following a statistical approach, Kaiser-Mentler-O and Bartlett's indices were tested. In addition, eigenvalues analysis was conducted using Kaiser Criterion $(<1)$, Cattel criterion (scree plot graphical display) and Parallel analysis, suggesting the amount of factors to retain. Theoretic definitions regarding SMPS-2 constructs and semantic content were considered to define which factor solution was more satisfying. Sample adequacy measure of each item was performed using anti-image matrix (MAS> $.70 r<.09$ ). Factor loadings above .35 were kept in the exploratory model (Hair, Black, Babin, Anderson, $\&$ Tatham, 2005). These criteria were repeatedly used until an acceptable factor solution was obtained.

For the CFA, outliers were assessed through Mahalanobis squared distance $\left(\mathrm{D}^{2}\right)$, given that the absence of such cases is a prerequisite for CFA. Normality was also verified through data univariate distribution by skewness (Sk) and kurtosis $(\mathrm{Ku})$, and for multivariate distribution (Mardia coefficient for multivariate kurtosis) (ISKI $<3.0$ and IKuI $<10$ ) (Kline, 2012). Since our data did not obtain normality, we performed a Bollen-Stine bootstrap procedure to obtain a corrected Chi-squared value of the estimated coefficients for the Maximum Likelihood Estimator (Marôco, 2010). While the literature has suggested a cutoff point of .70 as adequate for the factor loadings (Hair et al., 2005), since this is SMPS-2's first empirical evaluation in its Brazilian version, we opted to set loadings above .50 as acceptable, as suggested in the literature (Brown, 2012; Kline, 2012). In addition, we used a Bootstrapping technique to test the significance of each item factor loading with its factor (MacCallum, Browne, \& Sugawara, 1996).

Thus, the SMPS-2 final model was tested through the most recommended fit indices in the literature (reference of expected values for each index): Chi-square ( $\chi^{2}$ and $p$-value), Goodness Fit Index (GFI > 0.95-90), Root Mean Square Error of Approximation (RMSEA < .08, I.C. 90\%), Normalized Fit Index (NFI $>0.95-90)$, Tucker-Lewis index (TLI $>0.95-90)$, Adjusted Goodness Fit Index (AGFI $>0.90)$, Normalized Chi-Square $\left(\chi^{2}\right.$ /degrees of freedom, recommended between 1.0 and 3.0) and Comparative Fit Index (CFI $>0.95-90)$. These indices aim to assess whether the model shows a good fit to the data, as proposed in the literature (Byrne, 2010; Hair et al., 2005; Kline, 2012). Power analysis were conducted to test our sample adequacy, based on RMSEA estimation, thus, considering a RMSEA varying from .05 to .08 with $5 \%$ significance our sample showed $81 \%$ power (MacCallum, Browne, \& Sugawara, 1996).

Convergent validity was assessed through the Average Variance Extracted (AVE) and values higher or close to .50 were considered acceptable indicators of convergent validity (Hair et al., 2005). Discriminant validity was assessed by comparing the AVE with the squared correlation between factors (Marôco, 2010). Composite reliability (CR) was calculated using CFA results, given that this measure provides the index of internal consistency of the instrument dimensions through the factor loadings of the respective items. Values greater than .70 were considered indicators of suitable composite reliability (Nunnally \& Berstein, 1994).

Invariance analysis of the measurement model in the sporting context between men and women was evaluated firstly with the individual adjustment of the model (same indexes used in the previous CFA) to each of the groups. Then invariance was assessed in both groups by comparing the free model (with factor weights and covariances of free factors) with a constrained model in which the factor weights and covariances of the two groups were fixed. A statistical significant difference of the two models was evaluated with a Chi-Square test (Marôco, 2010).

\section{Step three - Temporal validity \\ Participants and data collection}

After the translation and adaptation to Portuguese language and construct validation, 80 athletes from different sports of the state of Paraná were selected by a non-probability convenience approach for the temporal stability analysis (test-retest reliability) of the scale. This sample was independent from the one previously analyzed. Athletes answered questionnaires at two different times (test-retest) with an interval of 7 days after initial testing (Marôco, 2010). All athletes signed an Informed Consent Form.

\section{Instrument and procedures}

The instrument used was the Sport-Multidimensional Perfectionism Scale-2 (SMPS-2), which was translated and adapted to Brazilian context in Step 1 and validated as to construct in Step 2 Regarding data collection, we sent the consent form to the athletes that agreed to participate in our temporal validity sample. Again, data collection was performed where training sessions took place, in a predetermined time by the coaches during the second half of 2012, with an interval of 7 days between test and retest.

\section{Data analysis}

Temporal stability was assessed through the intraclass correlation coefficient, verifying the test-retest reliability of the instrument. The minimum index $(r>.75)$ recommended by the literature (Nunnally \& Bernstein, 1994) was adopted for this study.

\section{Results}

\section{Content validity}

All SMPS-2 dimensions obtained clarity of language and practical relevance coefficients above .81 . This finding indicated that the translated and adapted version of the SMPS-2 presents clear language to Portuguese, while also being relevant and pertinent to the Brazilian sporting context.

SMPS-2 item classification agreement among judges (Kappa coefficient) for Personal Standards, Concern over Mistakes, 
Perceived Parental Pressure, Perceived Coach Pressure, Doubts about Action and Organization dimensions was .87, indicating that the evaluators found that SMPS-2 items corresponded to the underlying dimensions. Moreover, the expert group (researchers and evaluators judges) evaluated judges' comments and suggestions regarding the suitability of the items. There was no need to change the content of the adapted instrument after the pilot study.

\section{Descriptive statistics and internal reliability}

Descriptive analysis showed that athletes resorted to the five response possibilities for each of the 42 items of SMPS-2. Average response for the items ranged from $2.27 \pm 1.26$ and 3.79 \pm 1.03 , respectively illustrating the lowest and highest averages in items 19 ("I feel like I am criticized by my parents for doing things less than perfectly in competition") and 1 ("If I do not set the highest standards for myself in my sport, I am likely to end up a second-rate player"). General index of internal reliability of the SMPS-2 was .94. However, as it is a multidimensional scale, it is more important to calculate the reliability of each dimension separately. Cronbach's alpha for each dimension was satisfactory, ranging from $\alpha=.70$ to $\alpha=.90$. Item-scale correlations ranged from $.50 \leq r \leq .80$, indicating moderate to strong correlation between dimensions and their items. Factor weights (correlations between individual items and their factors) are considered significant when the value is equal or greater than $.50(\mathrm{PF} \geq .50)$.

\section{Exploratory factor analysis}

Analyzing the correlation patterns among items within their theoretical dimensions suggested inconsistencies with SMPS-2's factor structure in the Portuguese translated version. Low and not significant item vs. item correlation $(<.20)$ were observed among items within dimensions PS, DA, PPP and COM, showing potential problems for construct validity evaluation. Further, several items had strong correlations with items in other dimensions, indicating possible dimensionality problems. EFA analysis with the 42 translated items showed adequate KMO (.92) and significant Bartlett test $(p=.001)$. Kaiser criterion suggested 8 factors to retain, while Catell criteria and Parallel analysis pointed to 4 factors, therefore we tested 4 to 8 factor solutions. Solutions with 7 and 8 factors were discarded due to poor item distribution among dimensions, with factors containing only one or two items. Next, we tested a six factors model, hypothesizing to find the same structure as the original SMPS-2. However, communalities ranged from .25 to .68 , with items 5 , $16,21,22,26,31$ and 37 showing low FL $(<.50)$. Also, items $23,30,35$ had factor loadings below .32 (expecting at least $10 \%$ explanation of the latent factor). Not surprisingly, most of these items showed problems with correlation, as stated beforehand. Items 2, 6, 8, 10, 13, 16, 22, 21, 23, 24, 33, 36 loaded or had cross loadings with higher magnitude on factors different from the ones initially hypothesized. Specifically, we observed pro- blems with the factors PCP and PS, since three items originally hypothesized as pertaining to Personal Standards factor, actually loaded on Organization (33 and 36). Perceived Coach Pressure, on the other hand, had problems with items 22, 26, 30 and 35.

Since our six factorial solution was not acceptable, we returned to the analysis of the correlation matrix and observed a strong association between items hypothesized as belonging to Personal Standards and Organization. While this association has been reported repeatedly in the literature and some reports suggest that both dimensions configure a higher order dimension named Perfectionistic Strivings, we opted to merge the items and evaluate if they would load into one single factor. A five factor solution showed communalities ranging from .25 to .69 , with items 5, 16, 21, 22, 23, 24, 26, 28, 31, 32, 35, 36, 42 with low values $(<.50)$. Also, items 30 and 42 had factor loadings below 0.32 (expecting at least $10 \%$ explanation of the latent factor). Items $1,8,6,13,16,17,21,22,23,26,31,33,35$, 36,39 loaded or had cross loadings with higher magnitude on factors different from the ones initially hypothesized. Three dimensions had a sound structure (PPP, OR, DA), COM had three problematic items and PCP did not have items with loadings strong enough (above .32) to be kept. Finally, looking at the four factors solution, we observed the same problems with the same items already mentioned $(1,8,6,13,16,17,21,22,23,26,31$, $33,35,36,39)$, with some items from PCP loading into PPP.

Thus, based on theoretical considerations of the associations between PS and OR as Personal Strivings, inconsistencies with the entire PCP factor and the semantic incongruence of some items loading with magnitude on different conceptual dimensions, and on statistical considerations described before, we opted to exclude four items from COM, one item from OR, three items from PS and one item from DA. We also decided to exclude PCP because only one item remained, loading on PPP although theoretically unbalancing the factor (PPP) that had a sound structure. Finally, EFA on the remaining 27 items had good KMO (.92) and significant Bartlett indicator $(P=.001)$. All criteria for factors to retain suggested a 4 for factor solution. Communalities varied from .48 to .69 , deemed acceptable. Three items (1, 8 and 37) did not load higher than .30, and were also excluded; all other items had loadings higher than .40 with no cross loadings (Table 2). This four factorial solution with 24 items was found satisfactory to be tested with CFA, with factors named Personal Standards and Organization, Perceived Parental Pressure, Doubts in Action, and Concerns over Mistakes.

\section{Confirmatory factor analysis}

When the SMPS-2 model was subjected to the CFA it showed differences in relation to the extent of the original version of the instrument with six dimensions, since the exploratory analysis showed that the 6 initial factors of the SMPS-2 original version did not establish well in the Brazilian version. Thus, the model analyzed by the CFA postulates the existence of four latent factors (Personal Standards-Organization, Concern over Mistakes, Perceived Parental Pressure, and Doubts about Action). 
Table 2. EFA of the Brazilian version of the SMPS-2 with 4 factors and 24 items.

\begin{tabular}{|c|c|c|c|c|}
\hline Items of the SMPS-2 & COM & PPP & DA & OPS \\
\hline $\begin{array}{l}\text { 28. Se um companheiro de equipe ou adversário (que joga numa posição parecida com a minha) joga } \\
\text { melhor do que eu durante a competição, sinto que falhei de alguma maneira. }\end{array}$ & .57 & & & \\
\hline 32. Se eu não vou bem sempre que estou competindo, sinto que as pessoas não me respeitam como atleta. & .50 & & & \\
\hline 39. As pessoas provavelmente me desvalorizarão se eu cometer erros na competição. & .73 & & & \\
\hline $\begin{array}{l}\text { 42. Se eu jogo bem, mas cometo apenas um erro óbvio durante o jogo inteiro, eu me sinto desapontado } \\
\text { com meu desempenho. }\end{array}$ & .50 & & & \\
\hline 4. Meus pais estabelecem altos niveis de desempenho para mim em meu esporte. & & .60 & & \\
\hline 7. Em competição, eu nunca sinto que posso atender às expectativas de meus pais. & & .67 & & \\
\hline 11. Somente um desempenho excelente durante a competição é bom o suficiente para minha família. & & .57 & & \\
\hline 15. Meus pais sempre tiveram expectativas mais elevadas do que eu em relação a meu futuro no esporte. & & .63 & & \\
\hline $\begin{array}{l}\text { 19. Eu sinto que sou criticado por meus pais quando tenho um rendimento abaixo da perfeição nas com- } \\
\text { petições }\end{array}$ & & .63 & & \\
\hline 25. Na competição, eu sinto que nunca posso estar à altura do nivel de desempenho esperado por meus pais. & & .68 & & \\
\hline 29. Meus pais esperam excelência de mim em meu esporte. & & .62 & & \\
\hline 38. Eu sinto que meus pais nunca tentam entender completamente os erros que eu cometo na competição. & & .48 & & \\
\hline 40. Meus pais querem que eu seja melhor do que todos os outros atletas que jogam meu esporte. & & .62 & & \\
\hline 3. Geralmente, me sinto inseguro se meu treinamento efetivamente me prepara ou não para a competição. & & & .58 & \\
\hline 12. Eu geralmente me sinto inseguro sobre o quão adequadas são minhas práticas pré-competição. & & & .48 & \\
\hline 14. Eu raramente sinto que meu treinamento me prepara completamente para a competição & & & .45 & \\
\hline 20. Antes da competição, eu raramente me sinto satisfeito com meus treinamentos. & & & .42 & \\
\hline 9. Eu tenho e sigo uma rotina pré-competição. & & & & .64 \\
\hline 18. Eu sigo passos pré-planejados para me preparar para a competição. & & & & .65 \\
\hline 27. Eu sigo uma rotina para entrar em um bom estado mental antes da competição. & & & & .62 \\
\hline 33. Eu tenho metas extremamente altas em meu esporte. & & & & .55 \\
\hline 34. Eu desenvolvo planos que determinam como eu quero jogar durante a competição. & & & & .55 \\
\hline 36. Eu defino metas mais elevadas a serem alcançadas do que a maioria dos atletas que jogam meu esporte. & & & & .40 \\
\hline 41. Eu estabeleço planos que destacam as estratégias que eu uso quando estou em competição. & & & & .54 \\
\hline Eigenvalue & 1.18 & 8.74 & 1.44 & 2.41 \\
\hline Percentual of Explained Variance & 4.32 & 32.37 & 5.32 & 8.93 \\
\hline
\end{tabular}

Note: Item numbers were kept equal to the original instrument to guide the reader; however we kept the Portuguese language in order to report the items and their translations.

Based on the assessment of items individual reliability of SMPS-2, through the weights of the factor loadings, we found in the initial model (M1) that all the 24 items loaded into their factors with magnitude greater than $.50(p<.001)$. Moreover, the model with 24 items obtained acceptable fit $\left[\chi^{2}(246)=550.68 ; \chi^{2} / g l=2.24 ; \mathrm{CFI}=.92 ; \mathrm{GFI}=.90 ; \mathrm{AGFI}=\right.$ $.89 ; \mathrm{TLI}=.91 ; \mathrm{RMSEA}=.05$ (C.I. .05- .07); $\mathrm{AIC}=658.62$; $\mathrm{BIC}=873.54 ; \mathrm{MECVI}=1.69]$. Nevertheless, the Modification Indexes suggested correlations between measure errors of items from the same factors. Thus, the final model (M2) showed a correlation between the errors of items 7 and 11, 9 and 18, 19 and 29. These correlations between the errors were weak $(r<.30)$ and between items from the same factor, which does not disturb the adjustment and theoretical acceptance of the model.

The factor structure of the SMPS-2 modified model (M2), relative to the overall model fit had $\chi^{2}(243)=490.71$ and significant to $p<.001$, suggesting a poor fit. However, other absolute fit measures obtained values acceptable by the literature (GFI $=.92 ;$ RMSEA $=.05$, C.I. .04-.06). Regarding incremental fit measures, TLI (.93) and AGFI (.91) achieved the recommended level of .90 , supporting with credibility the acceptance of the modified model with 24 items. Concerning the parsimonious fit measures, standard Chi-square $\left(\chi^{2} / d f=2.01\right)$ was adequate to recommended levels from 1.0 to 3.0, and CFI (.94) achieved the recommended level $(>.90)$.

Further, the modified model was found to have better values in the indices based on information theory (AIC $=604.71$; $\mathrm{BIC}=831.50 ;$ MECVI $=1.55)$ compared to the initial model. The contents of the modified model (M2) showed a good fit for Brazilian athletes, proving satisfactory construct validity (factorial) of the instrument to Portuguese language. Figure 1 presents the estimates of the CFA final model (M2), which also describes the relationship between the dimensions and indicators in the solution found for the SMPS-2 data of validation. In the analysis of standard solution (or the estimated parameters after CFA), the factorial saturations $(\lambda)$ showed moderate and strong values ranging from .52 to .80 and their bootstrap replications $(p<.001)$ and Confidence Interval (I.C. 95\%) indicated stability of loadings estimation and consequent adjustment of the model fit to the data. All SMPS-2 items showed factor loadings with significant values in latent factors hypothesized. This indicates that the structure found in the EFA of the scale is replicated in the CFA. 


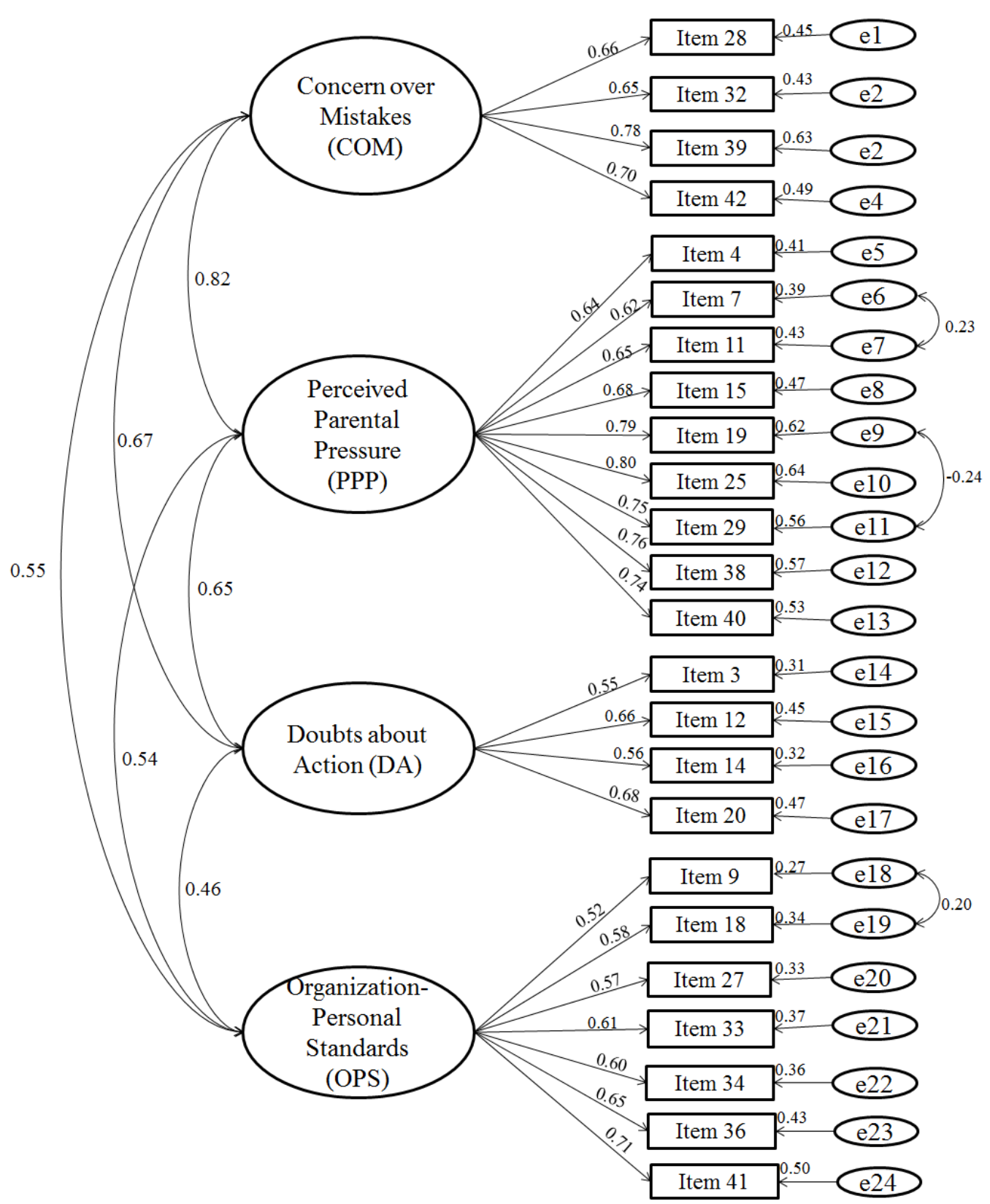

Figure 1. Bootstrap standardized coefficients, correlation between factors and error associated to each item, in the 4-factors SMPS-2 modified model with 24 items.

The values of average variance extracted (AVE) were as follows: Organization/Personal Standards (OPS) $=.38$; Concern over Mistakes $(\mathrm{COM})=.50$; Perceived Parental Pressure $(\mathrm{PPP})=.51$; and Doubts about Action $(\mathrm{DA})=.39$. Two factors (Personal Standards/Organization and Doubts about Action) have shown convergent validity below the limit (.50). The AVE values were compared with the squared correlations (SC) between the factors in order to evaluate the discriminant validity. We observed that the factor OPS revealed to be discriminant to the others (AVE $>$ SC), while the factors COM, PPP and DA showed higher SC between them than their AVE. This result is expected since COM, PPP and DA assess a similar construct, the perfectionist concerns.
The values of $\mathrm{CR}$ for internal consistency were as follows: Personal Standards/Organization $=.81$; Concern over Mistakes $=.80$; Perceived Parental Pressure $=.91$; and Doubts about Action $=.71$. All factors showed a satisfactory CR, which confirms the internal consistency of the SMPS-2 modified model with 24 items.

By analyzing the configurational invariance of the SMPS-2 modified model with 24 items between men and women $\left[\chi^{2}(484)\right.$ $=808.51 ; \chi^{2} / d f=1.67 ; \mathrm{CFI}=.92 ; \mathrm{GFI}=.89 ; \mathrm{TLI}=.92 ; \mathrm{RM}-$ $\mathrm{SEA}=.041(.03-.06) ; \mathrm{P}(\mathrm{RMSEA}<.05)=.90]$, we observed that the model showed an acceptable fit between male athletes and female, indicating that the proposed structure remains stable for both groups. We also found that the model with fixed 
constricted factor weights in athletes (men x women) did not show an adjustment significantly worse than the model with free parameters $\left[\chi_{\text {dif }}^{2}(20) 29.157, p=.085\right]$, i.e., the model with fixed factor weights fits well to both groups as the model with free parameters, showing the metric equivalence of the measure weights between men and women. Nevertheless, the structural invariance of the model was not obtained $\left[\chi_{\text {dif }}^{2}(30)=49.696\right.$; $p=.013$ ], demonstrating that the levels of correlation between factors are not the same for both groups. This demonstrates the partial invariance of the Brazilian version of the SMPS-2, since configurational and metric invariance were observed.

Thus, the numbering and reordering of the items by the four dimensions were corrected for the validation process completion of the SMPS-2 with 24 items: Personal Standards-Organization (items 4, 9, 13, 17, 18, 19, 23 ); Concern over Mistakes (items 14, 16, 21, 24); Perceived Parental Pressure (items 2, 3, 5, 8, 10, 12, 15, 20, 22); and Doubts about Action (items 1, 6, 7, 11).

\section{Temporal validity of the SMPS-2}

The intraclass correlation indicated the confirmation of test-retest reliability (temporal stability) of the scale. All items obtained coefficients above the minimum ratio recommended by the literature $(r>.75)$. By grouping the 24 items the average intraclass correlation was found to be .81 , indicating the temporal stability of the scale items. As it is a multidimensional instrument, it was found that all SMPS-2 dimensions showed intraclass correlation coefficient between $r=.76$ and $r=.85$, which indicates a strong reliability between test and retest for the validation sample.

\section{Discussion}

This is the first study to conduct a cross-cultural adaptation and validation of a sport-specific perfectionism characteristic scale to Brazilian Portuguese. This is also the first study to show psychometric evidence for the SMPS-2 with a high performance athlete sample. Most psychometric properties reports have been conducted with college athletes (Gotwals \& Dunn, 2009; Gotwals et al., 2010). The Brazilian version of the SMPS-2 showed satisfactory results in content analysis, construct validity, and temporal validity. It is important to mention that the scale was reduced to 24 items distributed through 4 dimensions in contrast to the original 42 items SMPS-2, respecting individual reliability and adjustment criteria (Marôco, 2010). In a general sense, the SMPS-2 psychometric properties follow the findings of previous researchers (Gotwals \& Dunn, 2009; Gotwals et al., 2010).

It is our understanding that a validation process and psychometric properties analysis of psychological measure, such as perfectionism, is an ongoing continuous process requiring a multiple methods approach (Devellis, 2003). As a result we executed different methods and alternate approaches with different samples. In our research, each analysis corroborated the results of the previous one, thus verifying a cross-cultural adaptation and validation of SMPS-2. On the other hand, this manuscript also advances the literature with evidence not previously reported such as exploratory and confirmatory analysis with the same model, invariance analysis and temporal validity.

\section{Content validity}

Initially, our main target was to analyze the cross-cultural adaptation and content validity of the SMPS-2 into Portuguese language as a tool to assess the athletes' perfectionism traits in the sporting context. The SMPS-2 adapted and translated versions showed values of content validity similar to those found in the literature (Gotwals et al., 2010). The final structure of the test was comprised of six constructs (Personal Standards, Concern over Mistakes, Perceived Parental Pressure, Perceived Coach Pressure, Doubts about Action, and Organization), similar to the original scale (Gotwals \& Dunn, 2009). This consistency with the original scale allowed perfectionism to be evaluated in the Brazilian context in accordance to the literature. Our findings showed that the adaptation obtained agreement and relevance to the athletes of the pilot study, corroborating the results of the content validity analysis. This result also adds evidence for the content validity of the 6 factors of SMPS- 2 with a high performance athlete's sample.

\section{Exploratory and confirmatory factor analysis}

In a general sense, the Brazilian version of SMPS-2 showed satisfactory indicators of internal consistency and construct (exploratory and confirmatory) validity. However, to reach an adequate adjustment in the factor structure of the latent model, eighteen items which did not adjust properly in the EFA and were excluded. In addition, the factor 'Perceived Coach Pressure' was not retained and the factors 'Organization' and 'Personal Standards' were clustered. Thus, the final version was constituted by 24 items and 4 dimensions, with good model fit and few small correlations between errors of items from the same factor.

Reliability scores for each factor met internal consistency criteria (Cronbach's alpha) present in the literature, being equal or higher than .70 (Blunch, 2008; Hair et al., 2005). Similar results for reliability were found for each dimension of the scale separately confirming that the items are precise in their measures in relation to each dimension of origin. Internal consistency coefficients for the SMPS-2 were similar to the original scale's validation (Gotwals \& Dunn, 2009) and other scales evaluating perfectionism (e.g., Parker \& Adkins, 1995). Values for item-dimension correlation $(r>.50)$ were satisfactory (Table 2) (Nunnally \& Berstein, 1994).

SMPS-2's main inconsistencies with the original scale were verified with EFA and CFA. Initially, fifteen out of 42 items had problematic factor loadings and/or communalities indicators in the EFA and correlation matrix. Specifically, we observed problems with individual items within all dimensions, but two results need to be addressed. Firstly, in relation to the PS dimension, strong significant correlations were observed with OR items. Also, EFA results indicated items with cross loadings or 
changing loading magnitude between PS to OR. This result is not entirely surprising since reports have indicated the existence of a higher order perfectionism dimension (Perfectionistic Strivings) composed by PS and OR (Gotwals et al., 2012). One explanation is that PS and OR would be inclined as more adaptive perfectionism, even related to more self-determined outcomes and sport performance (Gotwals \& Dunn, 2010; Gotwals et al., 2012). Therefore, we chose to statistically evaluate a factor solution with fewer dimensions to perceive the behavior of PS and OR items all together. Because the PS items with enough criteria to be kept in the model and OR questions loaded together, we decided to merge both factors as 'Organization and Personal Standards' (OPS).

The second issue to be discussed was more intriguing, since it was related to the sport specific dimension, PCP. PCP as a whole factor did not demonstrate enough statistical evidence to be kept in the latent model. Although this result needs to be carefully analyzed, one possible explanation might be the Brazilian sporting structure and career development itself. It has been widely stated that our athletes deal with hard scenario to reach high performance (Brandão \& Vieira, 2013). Brazil's sport talent development programs are still scarce. Young athletes sports practice tend to contrast with a student and, sometimes, professional (not in sport) career (see Brandão \& Vieira, 2013 for a review). Especially in non-highly structured sports such as the ones in our sample, without a specific professionalization, counseling programs for early career stages are not connected to academic development program such as in the USA (Murphy, Blustein, Bohlig, \& Platt, 2011).

Although coaches' pressure exists (Dunn et al., 2006), our results suggest that it might not be the major influence to perfectionism development throughout a career, which seems to be marked by other expectancies and problems as shown by the solidity of other factors such as PPP, COM or OPS. Also, recent reports have shown that coaches pressure tend to become more relevant as higher the level of the competition, especially for elite athletes (Flet \& Hewitt, 2005; Murphy et al., 2011). Finally, since perfectionism is a trait continuously developed, but more influenced in early stages of career (Dunn et al., 2002), while the athlete is going through infanthood or adolescence, it seems reasonable to state that coaches might not be the strongest influence during this stage. However, these results still need to be further tested and analyzed with caution.

From a statistical standpoint, similar problems with adjustment item-item levels were also evidenced in the literature for items 8, 17, 2 and 30 (Gotwals \& Dunn, 2009) and 1, 2 and 24 (Gotwals et al., 2010). Our results reiterated the inconsistencies already reported within SMPS-2 items structure. In both studies the authors verified inconsistencies with the CFA model, choosing to conduct EFA to verify internal structure adequacy. In addition, some of the items excluded in our 24 items model were also reported with problems in the first version of the SMPS (Dunn et al., 2006). This finding suggest that both versions of the instrument (SMPS and SMPS-2) still require further research with different approaches to establish a more stable internal structure such as our CFA approach. Our CFA findings confirm the reliability of perfectionism as a multidimensional theoretical construct (previously analyzed and validated by Gotwals \& Dunn, 2009 and Gotwals et al., 2010), however, hereby evaluated by 24 items across in 4 dimensions.

Although our CFA results support the model's convergent validity, we identified some correlations between errors among items from the same factors (as seen in Figure 1). However, these correlation coefficients were weak $(<.40)$ and, according to the literature, doesn't affect the factor structure (Blunch, 2008; Byrne, 2010; Kline, 2012), which is the case of our study. Further, two factors (DA and OPS) have not achieved the satisfactory convergent validity (AVE $>.50)$, showing that this limitation must be explored for future studies. Furthermore, for discriminant validity, values pointed out for the discriminant ability between OPS with all other variables, as excepted, separating adequately a dimension oriented to Perfectionistic Strivings with the others directed to the construct of Perfectionistic Concerns (Dunn et al., 2006). However, it is important to highlight that some dimensions (DA and COM) did not perform well and need to be further investigated. Although this result might be explained by the theoretical hypothesis of approximation among the items as a Perfectionistic Concern higher order factor (Stoeber \& Otto, 2006), this result must be faced carefully as a potential colinearity within the instrument (Hair et al., 2005). Nevertheless, since other psychometric properties were deemed acceptable among dimensions, we opted to maintain the structure developed.

The SMPS-2 model adequacy was also evidenced with the invariance (configurational and metric) analysis considering gender. Our results indicated adjusted fitness without gender differences. However, structural invariance was not found, indicating that the levels of the correlation between factors are not the same for different groups (Byrne, 2010). Importantly, structural invariance does not assess the variability of the psychometric properties of the instrument, thus not compromising the structural reliability of the model (Sass, 2011).

These results reveal that our 24 items version is flexible enough to be used among male and female athletes, a primary psychometric condition to be tested to allow group comparison based on SMPS-2 as outcome (Marôco, 2010). These results are another original evidence of SMPS-2 internal consistency, yet not reported in the literature.

\section{Temporal validity}

All SMPS-2 items and dimensions proved satisfactorily correlated with their own retest and there were no observed negative correlations between items and dimensions (Nunnally $\&$ Berstein, 1994) were observed. The reliability analysis using the intraclass correlation coefficient showed that both the 24 items as the four dimensions of SMPS-2 showed no adherence to extremes, demonstrating the reliability of intraclass correlation values. The phenomenon of acquiescence (whether positive or negative) was not observed in any cases, which indicates that it is reliable data (Blunch, 2008). The SMPS-2 intraclass correlation results indicate the temporal validity of the Brazilian instrument to measure perfectionism. No study verifying the 
temporal validity of the scale was published in the literature to date. This is a novel finding that provides further support to the psychometric evidence of the SMPS-2.

\section{Limitations and practical implications}

Apart from what was conducted in this study, SMPS and SMPS-2 original validation studies tested CFA models but did not succeed in finding satisfactory adequacy (Gotwals \& Dunn, 2009; Gotwals et al., 2010). Authors opted then to use exploratory approaches (Principal Components, Principal Axis and Multidimensional Scaling) to verify and confirm SMPS and SMPS-2's internal factor structure because CFA models fitness was not adequate. Although the authors' solution to investigate internal structure was theoretically acceptable, CFA models are an inferential method to evaluate and confirm a latent model factor structure (Nunnally \& Berstein, 1994). CFA models allow observing a scales' latent functioning, besides explicitly considering measurement error (Jackson, Gillaspy Jr \& Purc-Stephenson, 2009; Marôco, 2010). However, our model tested and confirmed for the CFA had 24 items across 4 dimensions, according to the EFA model. This change in the original structure of the test is a limitation that needs attention. We addressed the need to adjust the test in our validation process; however, further studies are required to establish this version and its external validity.

Another limitation with this study is related to its geographical distribution of the sample. All our athletes were from Paraná state. However, all athletes participated in high level state or national competition and are native from different regions in Brazil. Future studies should approach these issues concerning crossed validation in a way the results may be generalized to other independent samples. Our innovation regards testing the Brazilian version with a non-college sample, as suggested by Gotwals and Dunn (2009). SMPS-2 psychometric properties behaved similarly to the Canadian version tested with college students (Gotwals et al., 2010) proving the scales' crossed validation among samples and cultures, strengthening its consistency and reliability.

Our results demonstrate that the SMPS-2 might provide relevant information to help sport psychologists and coaches in better understanding perfectionism amongst athletes, allowing practitioners to understand different dimensions and potentially giving parameters to psychological preparation in sports context (Stoeber \& Otto, 2006). However, further studies should replicate SMPS-2 psychometric properties testing with other samples and other cultures to confirm the factor solution stability found in our results, specifically with confirmatory approaches. Also, other psychometric properties need to be addressed such as external validity, responsiveness or even individual item parameters.

Similarly, criterion validity should also be further tested to explore the quality of the scale as a predicting variable to sports related variables. Since this is the first instrument to be validated to Brazilian Portuguese, more research is needed to establish evidence of SMPS-2 behavior in relation to perfectio- nism correlates and other perfectionism scales (Flett \& Hewitt, 2002; Haase \& Prapavessis, 2004). Specifically, it is relevant to suggest more studies to understand SMPS-2 behavior in relation to global perfectionism scales present in the literature (Frost et al., 1990; Hewitt \& Flett, 1991). Finally, SMPS-2 in its initial 24 items and 4 dimensions version has shown to be a reliable and validated measurement and needs to be further used in applied research among Brazilian athletes as a perfectionism evaluation instrument.

\section{References}

Blunch, N. (2008). Introduction to Structural Equation Modeling using SPSS and AMOS. London: Sage Publications.

Brandão, M.R.F., \& Vieira, L.F (2013). Athletes' Careers in Brazil: Research and Application in the Land of Ginga. In N. B. Stambulova, \& T. V. Ryba (Eds.), Athletes' Careers Across Cultures (pp. 43-52). London and New York, NY: Routledge.

Brown, T.A. (2012). Confirmatory factor analysis for applied research. Ney York: Guilford Press.

Byrne, B. (2010). Structural equation modeling with AMOS: Basic concepts, applications, and programming. Trenton, NJ: Lawrence Erlbaum.

Devellis, R. F. (2003). Scale development: Theory and applications. Thousand Oaks, CA: Sage.

Dunn, J.G.H., Causgrove Dunn, J.L., \& Syrotuik, D.G. (2002). Relationship between multidimensional perfectionism and goal orientations in sport. Journal of Sport \& Exercise Psychology, 24, 376-395.

Dunn, J.G.H., Gotwals, J.K., \& Causgrove Dunn, J. (2005). An examination of the domain specificity of perfectionism among intercollegiate student-athletes. Personality and Individual Differences, $38,1439-1448$

Dunn, J.G.H., Gotwals, J.K., Causgrove Dunn, J., \& Syrotuik, D.G. (2006). Examining the relationship between perfectionism and trait anger in competitive sport. International Journal of Sport and Exercise Psychology, 4, 7-24.

Dunn, J.G.H., Causgrove Dunn, J., Gotwals, J.K., Vallance, J.K.H, Craft, J.M., \& Syrotuk, D.G. (2006). Establishing construct validity evidence for the Sport Multidimensional Perfectionism Scale. Psychology of Sport and Exercise, 7, 57-79.

Flett, G.L., \& Hewitt, P.L. (2002). Preface. In G.L. Flett \& P.L. Hewitt (Eds.), Perfectionism: Theory, research and practice (pp. xi-xiv). Washington, DC: American Psychological Association.

Flett, G.L., \& Hewitt, P.L. (2002). Perfectionism and maladjustment: An overview of theoretical, definitional, and treatment issues. In G. L. Flett, \& P. L. Hewitt (Eds.), Perfectionism: Theory, research, and treatment (pp. 5-31). Washington, DC: American Psychological Association.

Flett, G.L., \& Hewitt, P.L. (2005). The perils of perfectionism in sports and exercise. Current Directions in Psychological Science, 14, 14-18.

Frost, R.O., Marten, P., Lahart, C., \& Rosenblate, R. (1990). The dimensions of perfectionism. Cognitive Therapy and Research, 14, 449-468.

Gotwals, J., \& Dunn, J.G.H. (2009). A Multi-Method Multi-Analytic Approach to Establishing Internal Construct Validity Evidence: The Sport Multidimensional Perfectionism Scale 2. Measurement in Physical Education and Exercise Science, 13, 71-92.

Gotwals, J., Dunn, J.G.H., Causgrove Dunn, J., \& Gamache, V. (2010). Establishing validity evidence for the Sport Multidimensional Perfectionism Scale-2 in intercollegiate sport. Psychology of Sport and Exercise, 11, 423-432. 
Gotwals, J.K., Stoeber, J., Dunn, J.G.H., \& Stoll, O. (2012). Are perfectionistic strivings in sport adaptive? A systematic review of confirmatory, contradictory, and mixed evidence. Canadian Psychology, 53, 263-279.

Haase, A.M., \& Prapavessis, H. (2004). Assessing the factor structure and composition of the Positive and Negative Perfectionism Scale in sport. Personality and Individual Differences, 36, 1725-1740.

Hair, J., Black, W., Babin, B., Anderson, R., \& Tatham, R. Multivariate Data Analysis. (2005). New Jersey: Pearson Educational.

Hernández-Nieto, R.A. Contributions to Statistical Analysis. (2002). Mérida: Universidad de Los Andes.

Hewitt, P.L., \& Flett, G.L. (1991). Perfectionism in the self and social contexts: Conceptualization, assessment, and association with psychopathology. Journal of Personality and Social Psychology, 60, 456-470.

Jackson, D.L., Gillaspy Jr , J.A., \& \& Purc-Stephenson, R. (2009). Reporting practices in confirmatory factor analysis: An overview and some recommendations. Psychological Methods, 14, 6-23.

Kline, R.B. (2012). Principles and Practice of Structural Equation Modeling. New York: The Guilford Press.

MacCallum, R.C., Browne, M.W., \& Sugawara, H.M. (1996). Power analysis and determination of sample size for covariance structure modeling. Psychological Methods, 1, 130-149.

Marôco, J. (2010). Análise de Equações Estruturais: Fundamentos teóricos, Software e Aplicações (Structural equation analysis: theoretical foundations, Software and applications). Pêro Pinheiro: Report Number.

Murphy, K.A., Blustein, D.L., Bohlig, A.J. \& Platt, M.G. (2011). The College-to-Career Transition: An Exploration of Emerging Adulthood. Journal of Counseling \& Development, 88, 174-181.

Nunnally, J.C., \& Berstein, I.H. Psychometric theory. New York: McGraw-Hill, 1994.

Okoli, C., \& Pawlowski, S.D. (2004). The Delphi method as a research tool: An example, design considerations and applications. Information and Management, 42, 15-29.

Parker, W.D., \& Adkins, K.K. (1995). A Psychometric Examination of the Multidimensional Perfectionism Scale. Journal of Psychopathology and Behavioral Assessment, 17, 323-334.

Pasquali, L. (2010). Instrumentação psicológica: fundamentos e práticas. Porto Alegre, Artmed.

Revelle, W. (2012). Psych: Procedures for Psychological, Psychometric and Personality Research. CRAN.

Sass, D.A. (2011). Testing measurement invariance and comparing latent factor means within a confirmatory factor analysis framework. Journal of Psychoeducational Assessment, 29, 347-363.

Serpa, S., Alves, P., \& Barreiros, A. (2004). Versão portuguesa da Multidimensional Perfectionism Scale (MPSp): processos de tradução, adaptação econfiabilidade. Lisboa: Laboratório de Psicologia do Desporto: Universidade Técnica de Lisboa, Lisboa.

Soares, M.J., Gomes, A.A., Macedo, A.F., \& Azevedo, M.H.P. (2003). Escala Multidimensional de Perfeccionismo: Adaptação à população portuguesa. Revista Portuguesa de Psicossomática, 5, 46-55.

Stoeber, J., \& Otto, K. (2006). Positive conceptions of perfectionism: Approaches, evidence, challenges. Personality and Social Psychology Review, 10, 295-319.

\section{Authors' note}

José Roberto Andrade do Nascimento Junior is affiliated with the State University of Maringá (Universidade Estadual de Maringá) as a Phd student in the graduate program in physical education UEM-UEL. He is a Phd visiting student in the Research in Sport Studies, School of Sport of the University of Stirling, Scotland, UK.

João Ricardo Nickenig Vissoci is a doctor in social psychology and affiliated with the Ingá College, Medicine Department. Research fellow in Duke University, Medicine Department.

David Lavallee has a doctorate in life and physical sciences (psychology) and is affiliated with the School of Sport, University of Stirling, Scotland, UK.

Lenamar Fiorese Vieira is a doctor in physical education and is affiliated with the State University of Maringá (Universidade Estadual de Maringá) and is a faculty member of the graduate program in physical education of the State University of Maringá/State University of Londrina (UEM-UEL).

\section{Corresponding author}

José Roberto Andrade do Nascimento Junior Rua TIetê, 614, Apto 15, 87020-210, Maringá-PR, Brasil Phone: 4491770812

Email: jroberto.jrs01@gmail.com /

Manuscript received on March 20, 2014

Manuscript accepted on March 10, 2015

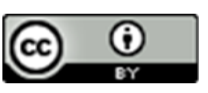

Motriz. The Journal of Physical Education. UNESP. Rio Claro, SP, Brazil - eISSN: 1980-6574 - under a license Creative Commons - Version 3.0 